\title{
Lectotypification of Beilschmiedia brandisii (Lauraceae)
}

\author{
Amal Bawri* and S.K. Borthakur \\ Department of Botany, Gauhati University, Guwahati - 781014, Assam, India. \\ *E-mail: amalbawri@gmail.com
}

\begin{abstract}
The name Beilschmiedia brandisii Hook.f. is lectotypified here.
\end{abstract}

Keywords: Assam, Beilschmiedia, Endemic, Lectotype

\section{Introduction}

Beilschmiedia Nees is one of the largest genera of the family Lauraceae with approximately 250 species and is widely distributed in tropical Asia and Africa (van der Werff, 2003). The generic name Beilschmiedia Nees was validly published in Plantae Asiaticae Rariores that listed two Indian species, $B$. roxburghiana Nees and B. fagifolia Nees (Nees, 1831). In the Indian context, Hooker (1886) enumerated 14 species in the Flora of British India. Santapau \& Henry (1973) reported nine species from India. In northeast India, five species are found to be distributed. Due to lack of detailed taxonomic account on the genus, the understanding of Indian Beilschmiedia is not completely known. The present work is part of the systematic studies on the family Lauraceae in northestern India. Beilschmiedia brandisii Hook.f., is an endemic species confined to Assam, Arunachal Pradesh, Meghalya and Sikkim in the northeast India. Hooker (1886) described this species based on the specimens collected by Brandis from Assam. It is mentioned in the protologue as: "ASSAM; in the Naraber Forest, Golaghat, Brandis". After critical examination of the protologue and the type material, it was confirmed that the author described the species based on more than one specimen and the need for lectotypification of this name was realised. Accordingly, after critical examination of type specimens at A, BM, BONN, CAL, E, G, HBG, GH, $\mathrm{K}, \mathrm{LINN}, \mathrm{MANCH}, \mathrm{NY}, \mathrm{P}$ and US through online databases and correspondences with the curators of these herbaria revealed that there are a total of four relevant specimens of the species, two specimens each at K (K000768638, K000768639) and HBG (HBG509723, HBG509724) collected by Brandis were traced. Of which one specimen (HBG509723) with both flowers and a fruit and the remaining three specimens (K000768638, K000768639 and HBG509724) are either with flowers or fruits. Since there are no other collection of the specimen by Brandis till the species was described in1886 and since Hooker provided detail characteristics of the fruits and flowers of the species in the protologue, the specimen HBG509723 is considered as a complete representative of the $B$. brandisii and hence the specimen has been designated here as the lectotype in accordance to Art. 9.2, 9.11 and 9.12 of ICN (McNeill et al., 2012).

Further in the protologue, the type locality was mentioned erroneously as "Naraber Forest, Golaghat". But in the present treatment, it is rectified as Nambor Forest, Golaghat as there is no place or locality known as "Naraber Forest in Golaghat (presently a district).

Beilschmiedia brandisii Hook.f., Fl. Brit. India 5: 123. 1886.

Fig. 1

Lectotype (designated here): INDIA, Assam: Nambor Forest, Golaghat, March 1879, D. Brandis s.n. (HBG509723, image!); isolecto (K000768638, image!, K000768639, image!, HBG509724, image!).

\section{Acknowledgements}

We are grateful to the Curators of the herbaria mentioned, for providing the information on the type specimens and authorities of $\mathrm{K}$ and HBG, for providing images of the type materials, for this study. We wish to thank the reviewer for the valuable suggestions. First author is also thankful to Science and Engineering Research Board (SERB), Govt. of India (PDF/2016/000264), for the financial assistance. 


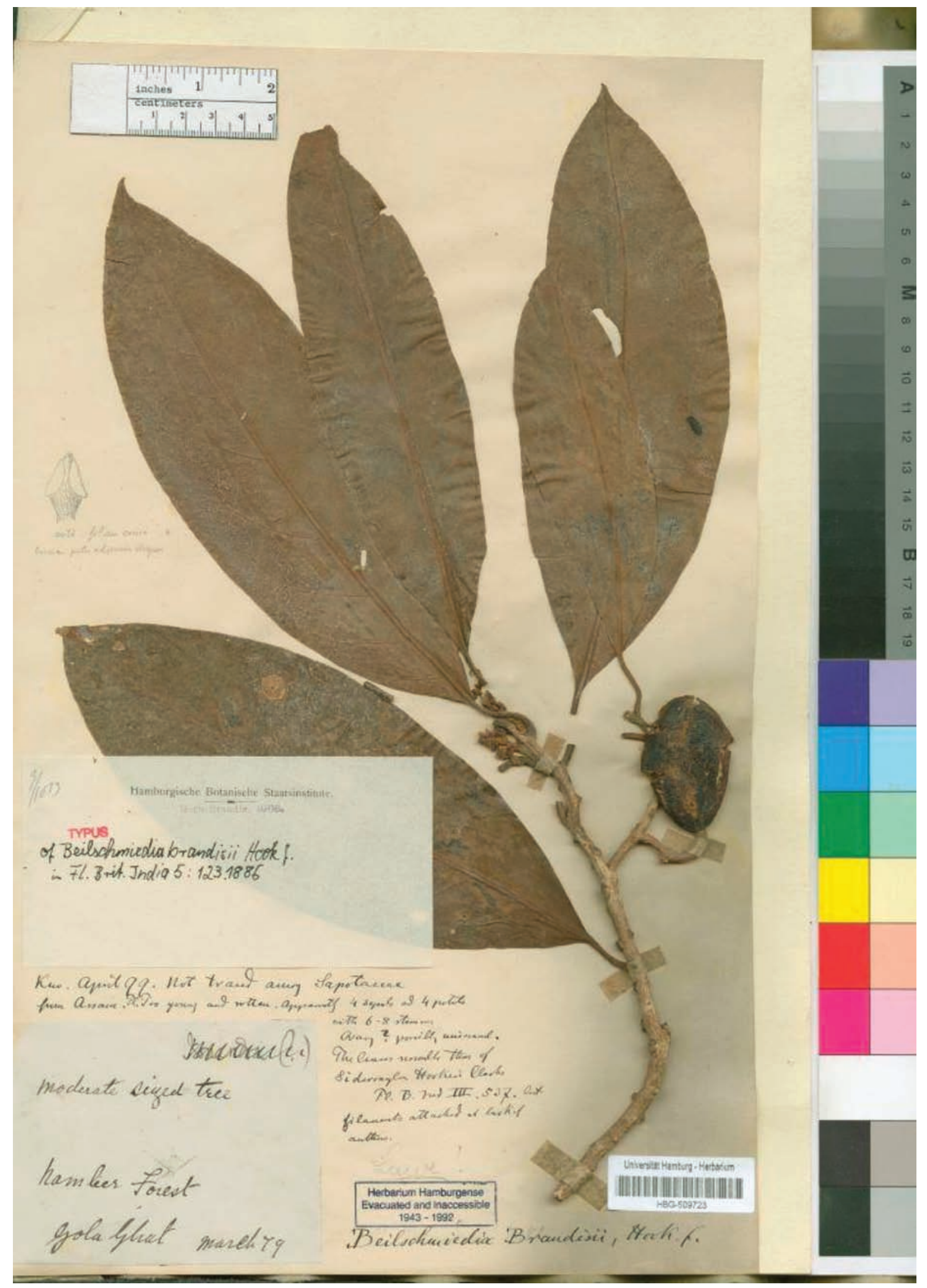

Fig. 1. Lectotype of Beilschmiedia brandisii Hook.f. (D. Brandis s.n., HBG509723). 


\section{Literature Cited}

Hooker, J.D. 1886. The Flora of British India. Vol. 5. L. Reeve \& Co., London. pp. 116-189.

McNeill, J., Barrie, F.R., Buck, W.R., Demoulin, V., Greuter, W., Hawksworth, D.L., Herendeen, P.S., Knapp, S., Marhold, K., Prado, J., Prud'homme van Reine, W.F., Smith, G.F., Wiersema, J.H. \& N.J. Turland (eds.) 2012. International Code of Nomenclature for algae, fungi, and plants (Melbourne Code). Adopted by the Eighteenth International Botanical Congress Melbourne, Australia, July 2011. Regnum Veg. 154. Koeltz Scientific Books, Königstein.
Nees von Esenbeck, C.G.D. 1831. Laurinae Indiae Orientalis. In: Wallich, N. (ed.), Plantae Asiaticae Rariores. Vol. 2. Treuttel \& Würtz, London. pp. $58-76$.

Santapau, H. \& A.N. Henry 1973. A dictionary of the flowering plants in India. Council of Scientific and Industrial Research, New Delhi.

Werff, H. van der 2003. A synopsis of the genus Beilschmiedia (Lauraceae) in Madagascar. Adansonia 25(1): 77-92.

Received: 25.4.2017

Revised and Accepted: 27.10.2017 